\title{
PENGARUH MINAT MENJADI GURU, LINGKUNGAN KELUARGA, DAN PRAKTIK PENGALAMAN LAPANGAN (PPL) TERHADAP KESIAPAN MENJADI GURU AKUNTANSI MAHASISWA PENDIDIKAN AKUNTANSI ANGKATAN 2013 FE UNY
}

\section{THE EFFECT OF THE INTEREST TO BE TEACHERS, FAMILY ENVIRONMENT, AND TEACHING PRACTICUM EXPERIENCE (TPE) ON THE READINESS OF ACCOUNTING TEACHER-TO-BE STUDENTS OF CLASS 2013 ACCOUNTING EDUCATION STUDY PROGRAM FE YSU}

\author{
Oleh: \\ Triana Yuniasari \\ Pendidikan Akuntansi Universitas Negeri Yogyakarta \\ triana.yuniasari@gmail.com \\ Moh. Djazari

\begin{abstract}
Staf Pengajar Jurusan Pendidikan Akuntansi Universitas Negeri Yogyakarta
\end{abstract}
\begin{abstract}
Abstrak
Penelitian ini bertujuan untuk mengetahui pengaruh Minat Menjadi Guru, Lingkungan Keluarga, dan Praktik Pengalaman Lapangan (PPL) terhadap Kesiapan Menjadi Guru Akuntansi Mahasiswa Pendidikan Akuntansi Angkatan 2013 FE UNY. Penelitian ini merupakan penelitian asosiatif. Teknik pengumpulan data menggunakan angket. Teknik analisis data menggunakan analisis regresi sederhana dan analisis regresi ganda. Hasil penelitian menunjukkan terdapat pengaruh positif Minat Menjadi Guru terhadap Kesiapan Menjadi Guru Akuntansi ditunjukkan dengan $\mathrm{r}_{\mathrm{x} 1 \mathrm{y}}=0,312$; $\mathrm{r}_{\mathrm{x} 1 \mathrm{y}}=0,097$; $\mathrm{t}_{\text {hitung }}>\mathrm{t}_{\text {tabel }}(3,134>1,9858)$; terdapat pengaruh positif Lingkungan Keluarga terhadap Kesiapan Menjadi Guru Akuntansi ditunjukkan dengan $\mathrm{r}_{\mathrm{x} 2 \mathrm{y}}=0,326 ; \mathrm{r}_{\mathrm{x} 2 \mathrm{y}}^{2}=0,106 ; \quad \mathrm{t}_{\text {hitung }}>\mathrm{t}_{\text {tabel }}$ (3,286>1,9858); terdapat pengaruh positif Praktik Pengalaman Lapangan (PPL) terhadap Kesiapan Menjadi Guru Akuntansi ditunjukkan dengan $r_{x 3 y}=0,546 ; r^{2}{ }_{x 3 y}=0,298 ; t_{\text {hitung }}>t_{\text {tabel }} \quad(6,217>1,9858)$; terdapat pengaruh positif Minat Menjadi Guru, Lingkungan Keluarga, dan Praktik Pengalaman Lapangan (PPL) secara bersama-sama terhadap Kesiapan Menjadi Guru Akuntansi ditunjukkan dengan $\mathrm{R}_{\mathrm{y} \cdot \mathrm{x}_{1} \mathrm{x}_{2} \mathrm{x}_{3}}=0,585 ; \mathrm{R}_{\mathrm{y} \cdot \mathrm{x}_{1} \mathrm{x}_{2} \mathrm{x}_{3}}=0,342 ; \mathrm{F}_{\text {hitung }}>\mathrm{F}_{\text {tabel }}(15,431>2,71)$.
\end{abstract}

Kata kunci: Kesiapan Menjadi Guru Akuntansi, Minat Menjadi Guru, Lingkungan Keluarga, Praktik Pengalaman Lapangan (PPL)

Abstract

This research aims to determine The effect of the Interest to be Teachers, Family Environment, and Teaching Practicum Experience (TPE) on the Readiness of Accounting Teacher-to-be Students of Class 2013 Accounting Education Study Program FE YSU. This research is associative research. The data collection technique used is the questionnaries. The data analysis technique used simple regression analysis and multi regression analysis. The result of this research were there is positive effect of the Interest to be Teachers on the Readiness of Accounting Teacher-to-be by $r_{x l y}=0,312 ; r_{x l y}^{2}=0,097 ; t_{\text {count }}>t_{\text {table }}(3,134>1,9858)$; there is positive effect of the Family Environment on the Readiness of Accounting Teacher-to-be by $r_{x 2 y}=0,326 ; r_{x 2 y}^{2}=0,106 ; t_{\text {count }}>t_{\text {table }}(3,286>1,9858)$; there is positive effect of the Teaching Practicum Experience (TPE) on the Readiness of Accounting Teacher-to-be by $r_{x 3 y}=0,546 ; r_{x 3 y}^{2}=0,298 ; t_{\text {count }}>t_{\text {table }}(6,217>1,9858)$; there is positive effect of the Interest to be Teachers, Family Environment, and Teaching Practicum Experience (TPE) joinly on the Readiness of Accounting Teacher-to-be by $R_{y \cdot x_{1} x_{2} x_{3}}=0,585 ; \quad R_{y . x_{1} x_{2} x_{3}}^{2}=0,342 ; \quad F_{\text {count }}>F_{\text {table }}$ $(15,431>2,71)$. 
Keywords: Readiness of Accounting Teacher-to-be, Interest to be Teachers, Family Environment, Teaching Practicum Experience (TPE).

\section{PENDAHULUAN}

Pendidikan merupakan salah satu cara yang dianggap paling tepat dalam meningkatkan kualitas sumber daya manusia. Dengan adanya pendidikan, manusia mendapatkan pengetahuan, keterampilan, serta pengalaman yang dapat membentuk kepribadian dan membantu berpikir kritis, sistematis, dan rasional dalam menghadapi suatu permasalahan. Pendidikan sebagaimana termaktub dalam Undang-Undang Nomor 20 Tahun 2003 Pasal 1 tentang Sistem Pendidikan Nasional yaitu sebagai berikut.

Pendidikan adalah usaha sadar dan terencana untuk mewujudkan suasana belajar dan proses pembelajaran agar peserta didik secara aktif mengembangkan potensi dirinya untuk memiliki kekuatan spiritual keagamaan, pengendalian diri, kepribadian, kecerdasan, akhlak mulia, serta keterampilan yang diperlukan dirinya, masyarakat, bangsa dan negara.

Pendidikan terdiri dari berbagai disiplin ilmu. Salah satunya adalah ilmu pengetahuan sosial. Dalam disiplin ilmu pengetahuan sosial, terdapat bidang ilmu ekonomi yang di dalamnya terdapat mata pelajaran Akuntansi. Dewasa ini, ilmu Akuntansi menjadi salah satu ilmu yang banyak dibutuhkan di dunia kerja. Semakin banyak perorangan dan institusi yang menyadari pentingnya ilmu Akuntansi dalam keberlangsungan bisnis dan perekonomian mereka. Oleh karena itu, dibutuhkan pendidikan yang berkualitas sesuai dengan Undang-Undang yang telah disebutkan sebelumnya, khususnya dalam ilmu Akuntansi.

Demi mewujudkan hal tersebut, dibutuhkan pendidik atau guru Akuntansi yang mumpuni karena guru merupakan salah satu faktor penentu keberhasilan pendidikan. Untuk dapat membentuk guru Akuntansi yang mumpuni, diperlukan persiapan. Dengan kata lain, kesiapan seorang guru Akuntansi adalah suatu hal yang penting.

Kesiapan Menjadi Guru Akuntansi adalah kesediaan dan kemampuan yang cukup baik yang dimiliki oleh seseorang dalam melaksanakan tugas utama sebagai guru Akuntansi. Kemampuan tersebut mencakup kemampuan secara fisik dan mental, termasuk kemampuan dalam penguasaan dan penyampaian materi pelajaran. Kesiapan Menjadi Guru Akuntansi akan menentukan berhasil tidaknya penyelenggaraan pendidikan, khususnya dalam mata pelajaran Akuntansi.

Namun yang terjadi di lapangan masih banyak persoalan mengenai rendahnya Kesiapan Menjadi Guru Akuntansi pada mahasiswa calon guru Akuntansi. Berdasarkan survei yang telah dilakukan oleh peneliti terhadap 91 Mahasiswa Pendidikan Akuntansi Angkatan 2013 FE UNY pada bulan Februari 2017, terdapat 55 mahasiswa atau sebanyak 60,43\% mahasiswa yang menyatakan Kesiapan Menjadi Guru Akuntansi mereka masih rendah. Hal tersebut sangat disayangkan mengingat mahasiswa jurusan kependidikan pada dasarnya dipersiapkan untuk menjadi guru.

Ada banyak faktor yang mempengaruhi Kesiapan Menjadi Guru Akuntansi, yaitu meliputi faktor internal dan eksternal. Faktor internal antara lain Minat Menjadi Guru, motivasi, kapasitas intelektual, pengetahuan, dan keterampilan. Sementara faktor eksternal antara lain meliputi informasi tentang dunia kerja, pengaruh dari berbagai lingkungan (Lingkungan Keluarga, lingkungan sekolah, dan lingkungan teman sebaya), serta pengalaman-pengalaman yang didapatkan dari berbagai kegiatan yang menunjang terbentuknya kesiapan untuk menjadi 
seorang guru Akuntansi, seperti Praktik Pengalaman Lapangan (PPL).

Salah satu faktor internal yang mempengaruhi Kesiapan Menjadi Guru Akuntansi adalah Minat Menjadi Guru. Minat Menjadi Guru adalah kecenderungan seseorang untuk menyukai dan memberikan perhatian yang besar kepada profesi guru sehingga pada akhirnya tertarik untuk bekerja menjadi guru. Seseorang yang memiliki minat yang tinggi terhadap profesi guru dan ingin bekerja menjadi guru akan berupaya meningkatkan kompetensi untuk menjadi seorang guru. Salah satu upaya yang dilakukan adalah dengan menempuh pendidikan keguruan.

Namun pada kenyataannya, tidak sedikit mahasiswa yang menempuh pendidikan keguruan bukan berdasarkan minatnya untuk menjadi seorang guru. Berdasarkan survei yang dilakukan oleh peneliti pada bulan Februari 2017, sebanyak 56 mahasiswa dari 91 Mahasiswa Pendidikan Akuntansi Angkatan 2013 FE UNY atau sebanyak $61,54 \%$ mahasiswa memiliki Minat Menjadi Guru yang rendah. Hal tersebut diduga dapat berpengaruh pada Kesiapan Menjadi Guru Akuntansi yang rendah pula.

Sementara itu, salah satu faktor eksternal yang mempengaruhi Kesiapan Menjadi Guru Akuntansi adalah Lingkungan Keluarga. Lingkungan Keluarga sengaja diciptakan untuk mempengaruhi anak. Sengaja diciptakan artinya Lingkungan Keluarga merupakan usaha sadar dari orang dewasa secara normatif untuk mempengaruhi perkembangan anak dalam bentuk pendidikan. Lingkungan Keluarga sangat mempengaruhi karier seseorang karena keluarga dapat membentuk dan meletakkan dasar-dasar bagi perkembangan anak agar anak dapat berkembang dengan baik.

Dalam karier sebagai seorang guru Akuntansi, Lingkungan Keluarga diduga turut mempengaruhi sejak mahasiswa calon guru Akuntansi menempuh pendidikan keguruan dalam rangka menyiapkan diri menjadi seorang guru. Mahasiswa Pendidikan Akuntansi Angkatan 2013 memiliki latar belakang keluarga yang berbeda-beda. Keluarga yang memiliki pandangan positif terhadap profesi guru akan mendukung anaknya untuk menjadi seorang guru. Dukungan tersebut berupa semangat yang diberikan oleh orang tua dan perhatian orang tua terhadap pendidikan keguruan yang ditempuh oleh anaknya. Begitu pula sebaliknya, jika dalam Lingkungan Keluarga tidak ada pandangan positif terhadap profesi guru Akuntansi maka dukungan yang diterima oleh mahasiswa calon guru Akuntansi untuk menjadi guru Akuntansi akan sangat minim. Apalagi jika Lingkungan Keluarga lebih menginginkan mahasiswa calon guru Akuntansi untuk memiliki pekerjaan selain guru Akuntansi. Hal tersebut diduga dapat berpengaruh terhadap Kesiapan Menjadi Guru Akuntansi.

Berdasarkan survei yang telah dilaksanakan oleh peneliti pada bulan Februari 2017, sebanyak 61 mahasiswa dari 91 Mahasiswa Pendidikan Akuntansi Angkatan 2013 FE UNY atau sebanyak $67,03 \%$ mahasiswa menyatakan bahwa keluarga turut mempengaruhi pilihan karier mereka. Dari jumlah tersebut, sebanyak 28 mahasiswa menyatakan bahwa Lingkungan Keluarga memberikan dukungan untuk menjadi seorang guru Akuntansi. Sementara itu, 33 mahasiswa atau sebanyak $54,10 \%$ mahasiswa menyatakan bahwa Lingkungan Keluarga menginginkan mahasiswa memiliki pekerjaan selain guru Akuntansi.

UNY menyelenggarakan pendidikan keguruan dengan mengadakan beberapa mata kuliah kependidikan, khususnya di Program Studi Pendidikan Akuntansi. Dengan menempuh mata kuliah kependidikan, diharapkan pemahaman mahasiswa calon guru Akuntansi tentang proses mengajar menjadi meningkat dan membentuk Kesiapan Menjadi Guru Akuntansi. Salah satu mata kuliah praktik yang sangat berpengaruh dalam membentuk 
Kesiapan Menjadi Guru Akuntansi adalah Praktik Pengalaman Lapangan (PPL). Tim Penyusun Panduan PPL/Magang III UNY (2014: 6) menyebutkan pengertian PPL sebagai berikut.

Program PPL/Magang III adalah program kegiatan Praktik Pengalaman Lapangan (PPL)/Magang III yang tujuannya adalah mengembangkan kompetensi mengajar mahasiswa sebagai calon guru/pendidik atau tenaga kependidikan.

Berdasarkan wawancara yang dilakukan oleh peneliti dengan Mahasiswa Pendidikan Akuntansi Angkatan 2013 FE UNY, permasalahan yang sering terjadi pada pelaksanaan Praktik Pengalaman Lapangan I (Micro Teaching) dan Praktik Pengalaman Lapangan II yaitu kurangnya keterampilan berbicara di depan kelas yang mengakibatkan kurang maksimalnya penyampaian materi pelajaran, kurangnya rasa percaya diri mahasiswa, kurangnya pengetahuan dalam mengelola kelas, kurangnya keterampilan dalam menciptakan dan menggunakan media pembelajaran, serta kurangnya keterampilan memberikan penguatan dan motivasi kepada siswa. Padahal dengan adanya Praktik Pengalaman Lapangan (PPL) ini mahasiswa diharapkan menjadi lebih siap untuk melaksanakan tugasnya sebagai seorang guru. Berdasarkan survei yang telah dilakukan oleh peneliti pada bulan Februari 2017, diketahui bahwa sebanyak 51 mahasiswa dari 91 Mahasiswa Pendidikan Akuntansi Angkatan 2013 FE UNY atau sebanyak 56,04\% mahasiswa menyatakan Kesiapan Menjadi Guru Akuntansi mereka masih kurang meskipun telah melaksanakan Praktik Pengalaman Lapangan (PPL).

Berdasarkan paparan tersebut, peneliti tertarik untuk melakukan penelitian dengan judul "Pengaruh Minat Menjadi Guru, Lingkungan Keluarga, dan Praktik Pengalaman Lapangan (PPL) Terhadap Kesiapan Menjadi Guru Akuntansi
Mahasiswa Pendidikan Akuntansi Angkatan 2013 FE UNY".

\section{METODE PENELITIAN \\ Desain Penelitian}

Desain penelitian ini adalah penelitian asosiatif yang bertujuan untuk mengetahui pengaruh variabel bebas yaitu Minat Menjadi Guru $\left(\mathrm{X}_{1}\right)$, Lingkungan Keluarga $\left(\mathrm{X}_{2}\right)$, dan Praktik Pengalaman Lapangan (PPL) $\left(\mathrm{X}_{3}\right)$ terhadap variabel terikat yaitu Kesiapan Menjadi Guru Akuntansi (Y). Penelitian ini menggunakan pendekatan kuantitatif, yaitu semua informasi atau data diwujudkan dalam angka dan analisisnya berdasarkan analisis statistik.

\section{Tempat dan Waktu Penelitian}

Penelitian ini dilaksanakan di Program Studi Pendidikan Akuntansi Fakultas Ekonomi Universitas Negeri Yogyakarta. Waktu penelitian dilaksanakan pada bulan Maret-April 2017.

\section{Subjek Penelitian}

Subjek dalam penelitian ini adalah Mahasiswa Pendidikan Akuntansi Angkatan 2013 FE UNY yang masih aktif per 19 Maret 2017 dan telah menempuh mata kuliah Praktik Pengalaman Lapangan (PPL) yang terdiri dari 3 kelas berjumlah 93 mahasiswa dengan rincian sebagai berikut:

Tabel 1. Subjek Penelitian

\begin{tabular}{|c|c|}
\hline Kelas & Jumlah Mahasiswa \\
\hline $\mathrm{A}$ & 43 mahasiswa \\
\hline $\mathrm{B}$ & 36 mahasiswa \\
\hline Unggulan & 14 mahasiswa \\
\hline Total & 93 mahasiswa \\
\hline
\end{tabular}

\section{Prosedur Penelitian}

Prosedur penelitian ini meliputi pendistribusian angket untuk variabel Kesiapan Menjadi Guru Akuntansi, Minat Menjadi Guru, Lingkungan Keluarga, dan Praktik Pengalaman Lapangan (PPL). Setelah semua data diperoleh kemudian dilakukan analisis dengan bantuan program pengolah data statistika untuk uji hipotesis 
yaitu analisis regresi sederhana dan analisis regresi ganda.

\section{Data, Intrumen, dan Teknik Pengumpulan}

a. Teknik Pengumpulan Data

Dalam penelitian ini teknik pengumpulan data yang digunakan yaitu angket atau kuesioner. Sugiyono (2007: 142) menyebutkan pengertian angket atau kuesioner yaitu "teknik pengumpulan data yang dilakukan dengan cara memberi seperangkat pertanyaan atau pernyataan tertulis kepada responden untuk dijawabnya". Jenis angket yang digunakan dalam penelitian ini adalah angket tertutup, yaitu angket yang telah dilengkapi dengan alternatif jawaban dan responden tinggal memilih salah satu jawaban. Dengan demikan, responden tinggal memberikan tanda checklist $(\checkmark)$ pada alternatif jawaban yang sudah tersedia sesuai dengan keadaan responden.

b. Instrumen Penelitian

Instrumen yang digunakan dalam penelitian ini untuk memperoleh data mengenai Kesiapan Menjadi Guru Akuntansi (Y), Minat Menjadi Guru $\left(\mathrm{X}_{1}\right)$, Lingkungan Keluarga $\left(\mathrm{X}_{2}\right)$, dan Praktik Pengalaman Lapangan (PPL) $\left(\mathrm{X}_{3}\right)$ adalah angket.

Indikator yang digunakan dalam penyusunan angket variabel Kesiapan Menjadi Guru Akuntansi yaitu empat kompetensi yang haris dimiliki guru, meliputi kompetensi pedagogik, kompetensi kepribadian, kompetensi profesional, dan kompetensi sosial. Indikator yang digunakan dalam penyusunan angket variabel Minat Menjadi Guru yaitu adanya keinginan untuk mendapatkan pengetahuan dan informasi mengenai profesi guru, perhatian yang besar terhadap profesi guru, perasaan senang karena memiliki pengalaman yang berhubungan dengan profesi guru, kemauan dan hasrat untuk menjadi guru, serta usaha untuk menjadi guru.

Indikator yang digunakan dalam penyusunan angket variabel Lingkungan Keluarga yaitu dukungan keluarga, keadaan ekonomi keluarga, dan latar belakang pendidikan anggota keluarga. Indikator yang digunakan dalam penyusunan angket variabel Praktik Pengalaman Lapangan (PPL) yaitu persiapan pembelajaran, praktik mengajar, menyusun dan mengembangkan media pembelajaran, menyusun dan mengembangkan alat evaluasi, serta kegiatan nonmengajar.

\section{c. Teknik Analisis Data}

Dalam penelitian ini terdapat 4 hipotesis. Hipotesis pertama, kedua, dan ketiga menyatakan terdapat pengaruh positif Minat Menjadi Guru, Lingkungan Keluarga, dan Praktik Pengalaman Lapangan (PPL) secara sendiri-sendiri terhadap Kesiapan Menjadi Guru Akuntansi Mahasiswa Pendidikan Akuntansi Angkatan 2013 FE UNY. Hipotesis keempat menyatakan terdapat pengaruh positif Minat Menjadi Guru, Lingkungan Keluarga, dan Praktik Pengalaman Lapangan (PPL) secara bersama-sama terhadap Kesiapan Menjadi Guru Akuntansi Mahasiswa Pendidikan Akuntansi Angkatan 2013 FE UNY.

Penelitian ini menggunakan teknik analisis data yang berupa analisis regresi sederhana dan analisis regresi ganda. Analisis regresi sederhana digunakan untuk menguji hipotesis pertama, kedua, dan ketiga. Analisis regresi ganda digunakan untuk menguji hipotesis keempat. 


\section{HASIL PENELITIAN DAN PEM- BAHASAN \\ Deskripsi Data Khusus}

a. Kesiapan Menjadi Guru Akuntansi

Berdasarkan data Kesiapan Menjadi Guru Akuntansi yang diperoleh dari angket Kesiapan Menjadi Guru Akuntansi, variabel Kesiapan Menjadi Guru Akuntansi memiliki skor tertinggi sebesar 51; skor terendah sebesar 38; mean sebesar 43,39; median sebesar 43; modus sebesar 40; dan standar deviasi sebesar 3,346. Jumlah kelas interval ditentukan dengan rumus $\mathrm{K}=1+3,3 \cdot \log 93$ hasilnya 7,495 dibulatkan menjadi 7. Rentang kelas $(51-38)+1=14$, panjang kelas diperoleh dari membagi rentang kelas dengan interval kelas yaitu 14:7=2. Adapun Tabel Distribusi Frekuensi Data Variabel Kesiapan Menjadi Guru Akuntansi dapat dilihat dari tabel berikut:

Tabel 2. Distribusi Frekuensi Data Variabel Kesiapan Menjadi Guru Akuntansi

\begin{tabular}{|c|c|c|}
\hline No. & Interval & Frekuensi \\
\hline 1. & $38-39$ & 9 \\
\hline 2. & $40-41$ & 23 \\
\hline 3. & $42-43$ & 17 \\
\hline 4. & $44-45$ & 19 \\
\hline 5. & $46-47$ & 13 \\
\hline 6. & $48-49$ & 6 \\
\hline 7. & $50-51$ & 6 \\
\hline \multicolumn{2}{|c|}{ Jumlah } & 93 \\
\hline
\end{tabular}

Berdasarkan tabel distribusi frekuensi tersebut, dapat digambarkan histogram sebagai berikut:

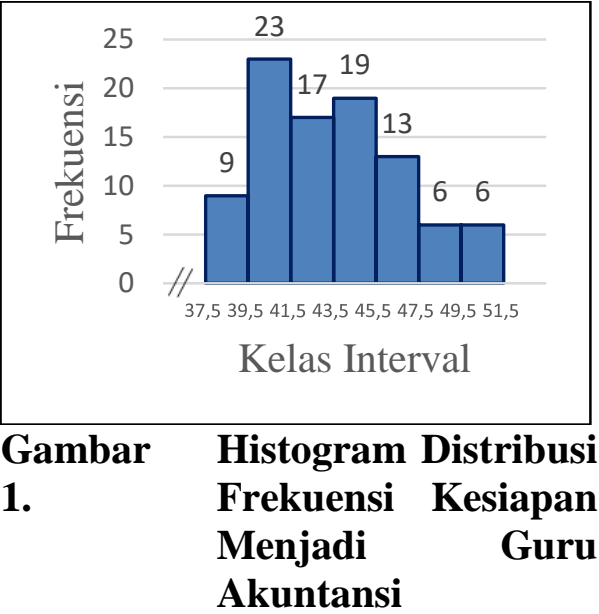

Pengkategorian kecenderungan variabel Kesiapan Menjadi Guru Akuntansi dapat dikategorikan menjadi tinggi, sedang, dan rendah. Kelompok tinggi apabila $x \geq 44$, kelompok sedang apabila $31 \leq x<44$, dan kelompok rendah apabila $\mathrm{x}<31$. Berdasarkan data Kesiapan Menjadi Guru Akuntansi dapat dibuat kategori kecenderungan sebagai berikut:

Tabel 3. Distribusi Kategori Kecenderungan

Kesiapan Menjadi Guru Akuntansi

\begin{tabular}{|c|c|c|c|}
\hline Interval & $\mathbf{F}$ & $\boldsymbol{\%}$ & $\begin{array}{c}\text { Kate- } \\
\text { gori }\end{array}$ \\
\hline $\mathrm{x} \geq 44$ & 44 & 47,312 & Tinggi \\
\hline $31 \leq \mathrm{x}<44$ & 49 & 52,688 & Sedang \\
\hline $\mathrm{x}<31$ & 0 & 0 & Rendah \\
\hline Jumlah & 93 & 100 & \\
\hline \multicolumn{4}{|c|}{ Berdasarkan tabel 3 tersebut, }
\end{tabular}
dapat dibuat diagram lingkaran sebagai berikut:

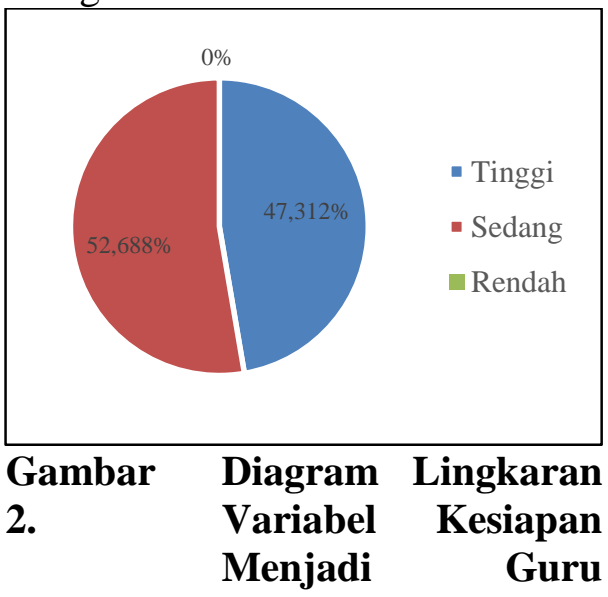




\section{Akuntansi}

Berdasarkan tabel 3 dan diagram lingkaran tersebut diketahui frekuensi variabel Kesiapan Menjadi Guru Akuntansi pada kategori tinggi sebanyak 44 mahasiswa $(47,312 \%)$, pada kategori sedang sebanyak 49 mahasiswa $(52,688 \%)$, dan pada kategori rendah sebanyak 0 mahasiswa $(0 \%)$.

b. Minat Menjadi Guru

Berdasarkan data Minat Menjadi Guru yang diperoleh dari angket Minat Menjadi Guru, variabel Minat Menjadi Guru memiliki skor tertinggi sebesar 50; skor terendah sebesar 16; mean sebesar 35,75; median sebesar 36; modus sebesar 37; dan standar deviasi sebesar 6,120. Jumlah kelas interval ditentukan dengan rumus $\mathrm{K}=1+3,3 \cdot \log 93$ hasilnya 7,495 dibulatkan menjadi 7. Rentang kelas $(50-16)+1=35$, panjang kelas diperoleh dari membagi rentang kelas dengan interval kelas yaitu 35:7=5. Adapun Tabel Distribusi Frekuensi Data Variabel Minat Menjadi Guru dapat dilihat dari tabel berikut:

Tabel 4. Distribusi Frekuensi Data Variabel Minat Menjadi Guru

\begin{tabular}{|c|c|c|}
\hline No. & Interval & F \\
\hline 1. & $16-20$ & 2 \\
\hline 2. & $21-25$ & 2 \\
\hline 3. & $26-30$ & 12 \\
\hline 4. & $31-35$ & 25 \\
\hline 5. & $36-40$ & 31 \\
\hline 6. & $41-45$ & 18 \\
\hline 7. & $46-50$ & 3 \\
\hline \multicolumn{2}{r|}{ Jumlah } & 93 \\
\hline
\end{tabular}

Berdasarkan tabel distribusi frekuensi tersebut, dapat digambarkan histogram sebagai berikut:

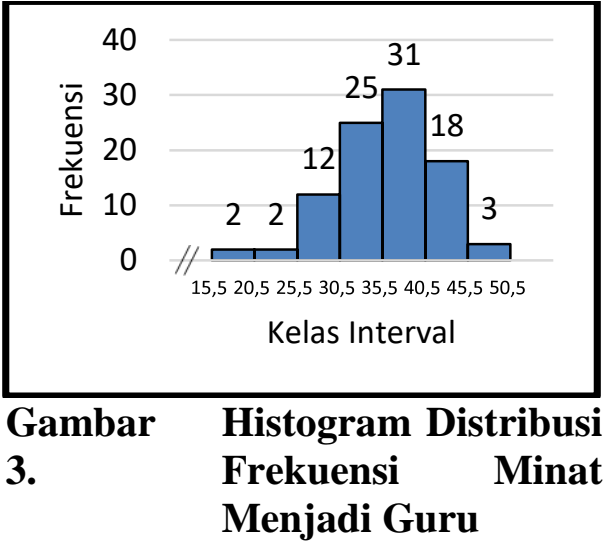

Pengkategorian kecenderungan variabel Minat Menjadi Guru dapat dikategorikan menjadi tinggi, sedang, dan rendah. Kelompok tinggi apabila $\mathrm{x} \geq 44$, kelompok sedang apabila $31 \leq \mathrm{x}<44$, dan kelompok rendah apabila $\mathrm{x}<31$. Berdasarkan data Minat Menjadi Guru dapat dibuat kategori kecenderungan sebagai berikut:

Tabel 5. Distribusi Kategori Kecenderungan Minat Menjadi Guru

\begin{tabular}{|c|c|c|c|}
\hline Interval & $\mathbf{F}$ & $\boldsymbol{\%}$ & $\begin{array}{c}\text { Kate- } \\
\text { gori }\end{array}$ \\
\hline $\mathrm{x} \geq 44$ & 7 & 17,204 & Tinggi \\
\hline $31 \leq \mathrm{x}<44$ & 70 & 75,269 & Sedang \\
\hline $\mathrm{x}<31$ & 16 & 7,527 & Rendah \\
\hline Jumlah & 93 & 100 & \\
\hline
\end{tabular}

Berdasarkan tabel 5 tersebut, dapat dibuat diagram lingkaran sebagai berikut:

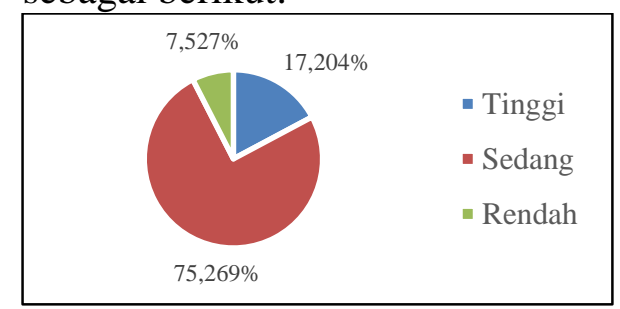

\section{Gambar Diagram Lingkaran 4. Variabel Minat Menjadi Guru}

Berdasarkan tabel 5 dan diagram lingkaran tersebut diketahui frekuensi variabel Minat Menjadi Guru pada kategori tinggi sebanyak 7 mahasiswa $(17,204 \%)$, pada kategori sedang sebanyak 70 
mahasiswa $(75,269 \%)$, dan pada kategori rendah sebanyak 16 mahasiswa $(7,527 \%)$.

c. Lingkungan Keluarga

Berdasarkan data Lingkungan Keluarga yang diperoleh dari angket Lingkungan Keluarga, variabel Lingkungan Keluarga memiliki skor tertinggi sebesar 31; skor terendah sebesar 15; mean sebesar 23,13; median sebesar 23; modus sebesar 25; dan standar deviasi sebesar 3,405 . Jumlah kelas interval ditentukan dengan rumus $\mathrm{K}=1+3,3 \cdot \log 93$ hasilnya 7,495 dibulatkan menjadi 7. Rentang kelas $(31-15)+1=17$, panjang kelas diperoleh dari membagi rentang kelas dengan interval kelas yaitu 17:7=2,429 dibulatkan menjadi 3 . Adapun Tabel Distribusi Frekuensi Data Variabel Lingkungan Keluarga dapat dilihat dari tabel berikut:

Tabel 6. Distribusi Frekuensi Data Variabel Lingkungan Keluarga

\begin{tabular}{|c|c|c|}
\hline No. & Interval & F \\
\hline 1. & $13-15$ & 1 \\
\hline 2. & $16-18$ & 7 \\
\hline 3. & $19-21$ & 23 \\
\hline 4. & $22-24$ & 29 \\
\hline 5. & $25-27$ & 23 \\
\hline 6. & $28-30$ & 8 \\
\hline 7. & $31-33$ & 2 \\
\hline \multicolumn{2}{|c|}{ Jumlah } & 93 \\
\hline
\end{tabular}

Berdasarkan tabel distribusi frekuensi tersebut, dapat digambarkan histogram sebagai berikut:

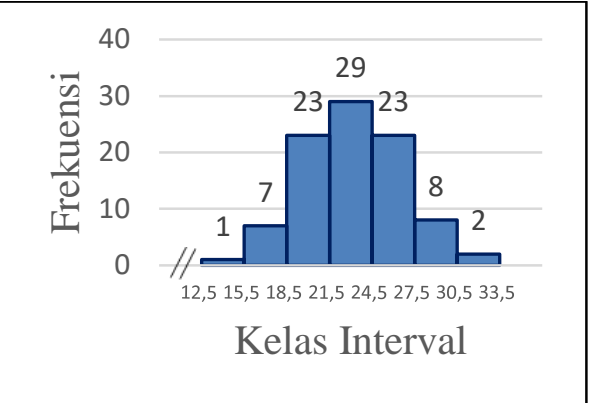

\section{Gambar Histogram Distribusi \\ 5. \\ Frekuensi \\ Lingkungan \\ Keluarga}

Pengkategorian kecenderungan variabel Lingkungan Keluarga dapat dikategorikan menjadi baik, cukup, dan tidak baik. Kelompok baik apabila $\mathrm{x} \geq 24$, kelompok cukup apabila $16 \leq x<23$, dan kelompok tidak baik apabila $\mathrm{x}<16$. Berdasarkan data Lingkungan Keluarga dapat dibuat kategori kecenderungan sebagai berikut:

Tabel 7. Distribusi Kategori

Kecenderungan

Lingkungan

Keluarga

\begin{tabular}{|c|c|c|c|}
\hline Interval & $\mathbf{F}$ & $\boldsymbol{\%}$ & $\begin{array}{c}\text { Kate- } \\
\text { gori }\end{array}$ \\
\hline $\mathrm{x} \geq 24$ & 40 & 43,011 & Baik \\
\hline $16 \leq \mathrm{x}<24$ & 52 & 55,914 & Cukup \\
\hline $\mathrm{x}<16$ & 1 & 1,075 & $\begin{array}{c}\text { Tidak } \\
\text { Baik }\end{array}$ \\
\hline Jumlah & 93 & 100 & \\
\hline
\end{tabular}

Berdasarkan tabel 7 tersebut, dapat dibuat diagram lingkaran sebagai berikut:

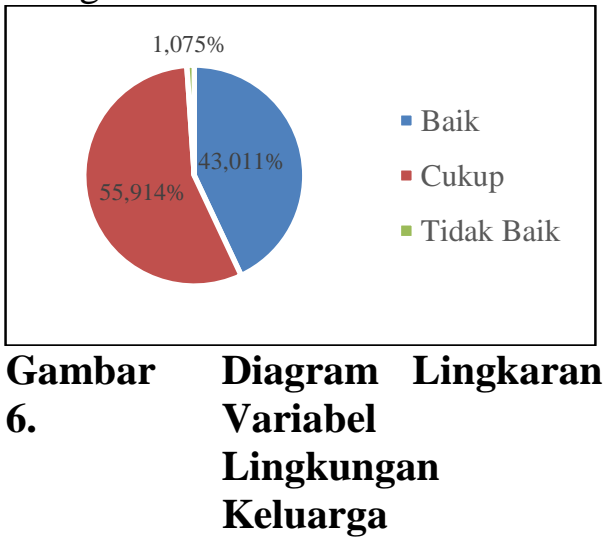


Berdasarkan tabel 7 dan diagram lingkaran tersebut diketahui frekuensi variabel Lingkungan Keluarga pada kategori baik sebanyak 40 mahasiswa $(43,011 \%)$, pada kategori cukup sebanyak 52 mahasiswa $(55,914 \%)$, dan pada kategori rendah sebanyak 1 mahasiswa $(1,075 \%)$.

d. Praktik Pengalaman Lapangan (PPL)

Berdasarkan data Praktik Pengalaman Lapangan (PPL) yang diperoleh dari angket Praktik Pengalaman Lapangan (PPL), variabel Praktik Pengalaman Lapangan (PPL) memiliki skor tertinggi sebesar 51; skor terendah sebesar 32; mean sebesar 40,25; median sebesar 40; modus sebesar 39; dan standar deviasi sebesar 3,534. Jumlah kelas interval ditentukan dengan rumus $\mathrm{K}=1+3,3 \cdot \log 93$ hasilnya 7,495 dibulatkan menjadi 7. Rentang kelas $(51-32)+1=20$, panjang kelas diperoleh dari membagi rentang kelas dengan interval kelas yaitu 20:7=2,857 dibulatkan menjadi 3 . Adapun Tabel Distribusi Frekuensi Data Variabel Praktik Pengalaman Lapangan (PPL) dapat dilihat dari tabel berikut:

Tabel 8. Distribusi Frekuensi Data Variabel Praktik Pengalaman Lapangan (PPL)

\begin{tabular}{|c|c|c|}
\hline No. & Interval & F \\
\hline 1. & $32-34$ & 3 \\
\hline 2. & $35-37$ & 12 \\
\hline 3. & $38-40$ & 43 \\
\hline 4. & $41-43$ & 20 \\
\hline 5. & $44-46$ & 8 \\
\hline 6. & $47-49$ & 5 \\
\hline 7. & $50-52$ & 2 \\
\hline \multicolumn{2}{|c|}{ Jumlah } & 93 \\
\hline
\end{tabular}

Berdasarkan tabel distribusi frekuensi tersebut, dapat digambarkan histogram sebagai berikut:

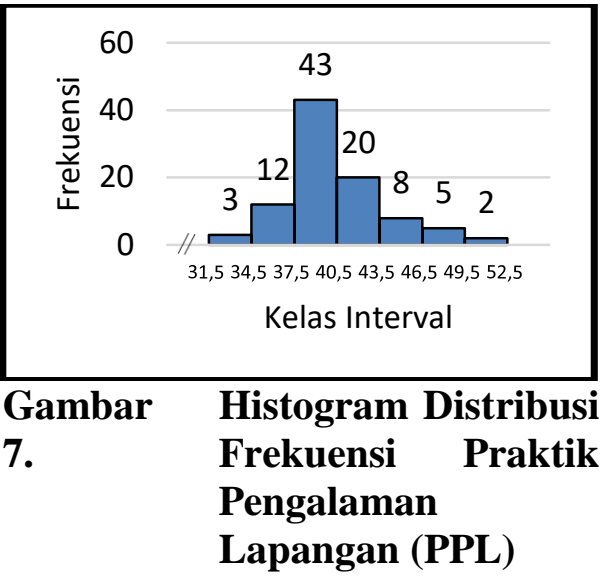

Pengkategorian kecenderungan variabel Lingkungan Keluarga dapat dikategorikan menjadi baik, cukup, dan tidak baik. Kelompok baik apabila $\mathrm{x} \geq 44$, kelompok cukup apabila $31 \leq x<43$, dan kelompok tidak baik apabila $\mathrm{x}<31$. Berdasarkan data Praktik Pengalaman Lapangan (PPL) dapat dibuat kategori kecenderungan sebagai berikut:

Tabel 9. Distribusi Kategori Kecenderungan Praktik Pengalaman Lapangan (PPL)

\begin{tabular}{|c|c|c|c|}
\hline Interval & $\mathbf{F}$ & \% & Kategori \\
\hline $\mathrm{x} \geq 44$ & 15 & 16,129 & Baik \\
\hline $\begin{array}{c}31 \leq \mathrm{x}< \\
44\end{array}$ & 78 & 83,871 & Cukup \\
\hline $\mathrm{x}<31$ & 0 & 0 & $\begin{array}{c}\text { Tidak } \\
\text { Baik }\end{array}$ \\
\hline Jumlah & 93 & 100 & \\
\hline
\end{tabular}

Berdasarkan tabel 9 tersebut, dapat dibuat diagram lingkaran sebagai berikut:

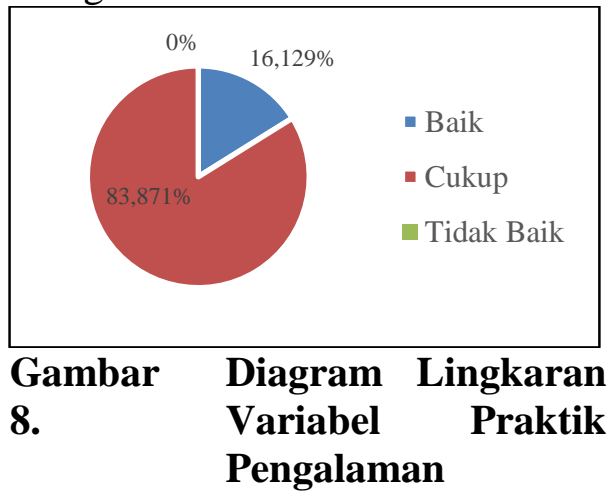




\section{Lapangan (PPL)}

Berdasarkan tabel 9 dan diagram lingkaran tersebut diketahui frekuensi variabel Praktik Pengalaman Lapangan (PPL) pada kategori baik sebanyak 15 mahasiswa $(16,129 \%)$, pada kategori cukup sebanyak 87 mahasiswa $(83,871 \%)$, dan pada kategori rendah sebanyak 0 mahasiswa $(0 \%)$.

\section{Uji Prasyarat Analisis}

a. Uji Linearitas

Tabel 10. Ringkasan Hasil

Uji Linearitas

\begin{tabular}{|l|c|c|c|}
\hline Variabel & $\boldsymbol{d} \boldsymbol{f}$ & $\begin{array}{c}\text { Harga } \\
\text { Fhitung }\end{array}$ & Ket. \\
\hline $\mathrm{X}_{1} \rightarrow \mathrm{Y}$ & $24 ;$ & 1,250 & Linear \\
& 67 & & \\
\hline $\mathrm{X}_{2} \rightarrow \mathrm{Y}$ & $14 ;$ & 1,686 & Linear \\
& 77 & & \\
\hline $\mathrm{X}_{3} \rightarrow \mathrm{Y}$ & $15 ;$ & 1,257 & Linear \\
& 76 & & \\
\hline
\end{tabular}

Berdasarkan tabel 10 tersebut, semua variabel dinyatakan linear.

b. Uji Multikolinearitas

Tabel Ringkasan Hasil Uji 11. Multikolinearitas

\begin{tabular}{|c|c|c|c|c|}
\hline $\begin{array}{c}\text { Var } \\
\text { iabe } \\
\quad 1\end{array}$ & $\mathbf{X}_{1}$ & $X_{2}$ & $\mathbf{X}_{3}$ & $\begin{array}{c}\text { Kesim- } \\
\text { pulan }\end{array}$ \\
\hline $\mathrm{X}_{1}$ & 1 & $\begin{array}{c}0,14 \\
5\end{array}$ & $\begin{array}{l}0,3 \\
27\end{array}$ & \multirow{3}{*}{$\begin{array}{l}\text { Tidak } \\
\text { terjadi } \\
\text { multi- } \\
\text { kolineari } \\
\quad \text { tas }\end{array}$} \\
\hline$X_{2}$ & $\begin{array}{l}0,1 \\
45\end{array}$ & 1 & $\begin{array}{c}0,3 \\
15\end{array}$ & \\
\hline$X_{3}$ & $\begin{array}{l}0,3 \\
27\end{array}$ & $\begin{array}{c}0,31 \\
5\end{array}$ & 1 & \\
\hline
\end{tabular}

Berdasarkan tabel 11 tersebut, semua data dinyatakan tidak terjadi multikolinearitas antar variabel bebas karena semua nilai koefisien korelasi antar masing-masing variabel bebas kurang dari 0,70.

\section{Uji Hipotesis}

a. Uji Hipotesis Pertama

Hasil penelitian ini menunjukkan persamaan garis regresi sederhana $\mathrm{Y}=37,286+0,171 \mathrm{X}_{1} ; \quad \mathrm{r}_{\mathrm{x} 1 \mathrm{y}}=0,312$; $r_{x 1 y}^{2}=0,097 ; t_{\text {hitung }} 3,134>1,98698$ $t_{\text {tabel }}$ sehingga dapat disimpulkan bahwa terdapat pengaruh positif Minat Menjadi Guru terhadap Kesiapan Menjadi Guru Akuntansi Mahasiswa Pendidikan Akuntansi Angkatan 2013 FE UNY, dengan demikian hipotesis pertama diterima. Minat Menjadi Guru mempengaruhi timbulnya Kesiapan Menjadi Guru Akuntansi sebesar $9,7 \%$.

Hasil penelitian ini juga selaras dengan penelitian yang dilakukan oleh Rina Susianti (2011) dengan judul "Pengaruh Minat Menjadi Guru dan Prestasi Belajar terhadap Kesiapan Menjadi Guru Mahasiswa Program Studi Pendidikan Akuntansi Angkatan 2008 FISE UNY". Hasil penelitian menunjukkan bahwa terdapat pengaruh positif Minat Menjadi Guru terhadap Kesiapan Menjadi Guru dengan nilai koefisien korelasi $\left(\mathrm{r}_{\mathrm{x} 1 \mathrm{y}}\right)$ sebesar 0,793 dan koefisien determinasi $\left(\mathrm{r}_{\mathrm{x} 1 \mathrm{y}}^{2}\right)$ sebesar 0,629 dan nilai $t_{\text {hitung }}$ sebesar $12,285>t_{\text {tabel }}$ sebesar 1,980. Selain itu penelitian ini juga selaras dengan penelitian yang dilakukan oleh Nurhayati (2010) dengan judul "Pengaruh Minat Menjadi Guru, Prestasi Belajar, dan PPL terhadap Kesiapan Menjadi Guru Mahasiswa Pendidikan Akuntansi Angkatan 2006 FISE UNY". Hasil penelitian menunjukkan bahwa terdapat pengaruh positif dan signifikan Minat Menjadi Guru terhadap Kesiapan Menjadi Guru Mahasiswa Pendidikan Akuntansi Angkatan 2006 FISE UNY dengan nilai 
koefisien korelasi $\left(\mathrm{r}_{\mathrm{x} 1 \mathrm{y}}\right)$ sebesar 0,600 ; nilai koefisien determinasi $\left(\mathrm{r}_{\mathrm{x} 1 \mathrm{y}}\right)$ sebesar 0,360 ; dan nilai $\mathrm{t}_{\text {hitung }}$ sebesar 7,304 dengan signifikansi 0,000 .

b. Uji Hipotesis Kedua

Hasil penelitian ini menunjukkan persamaan garis regresi sederhana $\mathrm{Y}=35,984+0,320 \mathrm{X}_{2} ; \quad \mathrm{r}_{\mathrm{x} 2 \mathrm{y}}=0,326$; $\mathrm{r}_{\mathrm{x} 2 \mathrm{y}}^{2}=0,106 ; \mathrm{t}_{\text {hitung }} 3,286<1,98698$ $\mathrm{t}_{\text {tabel }}$ sehingga dapat disimpulkan bahwa terdapat pengaruh positif Lingkungan Keluarga terhadap Kesiapan Menjadi Guru Akuntansi Mahasiswa Pendidikan Akuntansi Angkatan 2013 FE UNY, dengan demikian hipotesis kedua diterima. Lingkungan Keluarga mempengaruhi timbulnya Kesiapan Menjadi Guru Akuntansi sebesar $10,6 \%$

Hasil penelitian ini juga selaras dengan penelitian yang dilakukan oleh Nurul Mabitatul Muzdolifah (2014) dengan judul "Pengaruh Lingkungan Keluarga dan Sikap Keguruan terhadap Kesiapan Menjadi Guru pada Mahasiswa Pendidikan Akuntansi Angkatan 2011 Fakultas Ekonomi Universitas Negeri Yogyakarta”. Hasil penelitian menunjukkan bahwa terdapat pengaruh positif dan signifikan Lingkungan Keluarga terhadap Kesiapan Menjadi Guru dengan nilai koefisien korelasi $\left(\mathrm{r}_{\mathrm{x} 1 \mathrm{y}}\right)$ sebesar 0,457 dan koefisien determinasi $\left(\mathrm{r}_{\mathrm{x} 1 \mathrm{y}}^{2}\right)$ sebesar 0,209 dan nilai $t_{\text {hitung }}$ sebesar $5,728>t_{\text {tabel }}$ sebesar 1,660. Selain itu, penelitian ini juga selaras dengan penelitian yang dilakukan oleh Iis Setianingsih (2012) dengan judul "Pengaruh Praktik Pengalaman Lapangan (PPL) dan Lingkungan Keluarga terhadap Kesiapan Menjadi Guru pada Mahasiswa Program Studi
Pendidikan Akuntansi Angkatan 2008 FE UNY". Hasil penelitian menunjukkan bahwa terdapat pengaruh positif Lingkungan Keluarga terhadap Kesiapan Menjadi Guru pada Mahasiswa Program Studi Pendidikan Akuntansi Angkatan 2008 FE UNY dengan nilai $t_{\text {hitung }}$ lebih besar dari $t_{\text {tabel }}$ yaitu 4,159>1,664 dengan koefisien determinasi $\left(\mathrm{r}^{2} \mathrm{x} 2 \mathrm{y}\right)$ sebesar 0,163 .

c. Uji Hipotesis Ketiga

Hasil penelitian ini menunjukkan persamaan garis regresi sederhana $\mathrm{Y}=22,583+0,517 \mathrm{X}_{3} ; \quad \mathrm{r}_{\mathrm{x} 3 \mathrm{y}}=0,546$; $r^{2}{ }_{x 3 y}=0,298 ;$ thitung $6,217<1,98698$ $t_{\text {tabel }}$ sehingga dapat disimpulkan bahwa terdapat pengaruh positif Praktik Pengalaman Lapangan (PPL) terhadap Kesiapan Menjadi Guru Akuntansi Mahasiswa Pendidikan Akuntansi Angkatan 2013 FE UNY, dengan demikian hipotesis ketiga diterima. Praktik Pengalaman Lapangan (PPL) mempengaruhi timbulnya Kesiapan Menjadi Guru Akuntansi sebesar $29,8 \%$.

Hasil penelitian ini juga selaras dengan penelitian yang dilakukan oleh Iis Setianingsih (2012) yang berjudul "Pengaruh Praktik Pengalaman Lapangan (PPL) dan Lingkungan Keluarga terhadap Kesiapan Menjadi Guru pada Mahasiswa Program Studi Pendidikan Akuntansi Angkatan 2008 FE UNY" yang menunjukkan bahwa terdapat pengaruh positif Praktik Pengalaman Lapangan (PPL) terhadap Kesiapan Menjadi Guru pada Mahasiswa Program Studi Pendidikan Akuntansi Angkatan 2008 FE UNY dengan nilai $t_{\text {hitung }}$ lebih besar dari $t_{\text {tabel }}$ yaitu 4,510>1,664 dengan koefisien 
determinasi sebesar 0,186 . Penelitian lain yang sejalan dengan penelitian ini adalah penelitian yang dilakukan oleh Nurhayati (2010) dengan judul "Pengaruh Minat Menjadi Guru, Prestasi Belajar, dan PPL terhadap Kesiapan Menjadi Guru Mahasiswa Pendidikan Akuntansi Angkatan 2006 FISE UNY”. Hasil penelitian ini menunjukkan bahwa terdapat pengaruh positif dan signifikan PPL terhadap Kesiapan Menjadi Guru Mahasiswa Pendidikan Akuntansi Angkatan 2006 FISE UNY dengan nilai koefisien korelasi $r_{x 3 y}$ sebesar 0,508 ; nilai koefisien determinasi $\mathrm{r}^{2} \mathrm{x}$ 3y sebesar 0,258 ; dan nilai thitung sebesar 5,749 dengan signifikansi 0,000 .

d. Uji Hipotesis Keempat Hasil penelitian ini menunjukkan persamaan garis regresi ganda tiga prediktor $\mathrm{Y}=19,824+0,077 \mathrm{X}_{1}+0,161 \mathrm{X}_{2}+0,424$

$\mathrm{X}_{3} ; \quad \mathrm{R}_{\mathrm{y} \cdot \mathrm{x}_{1} \mathrm{x}_{2} \mathrm{x}_{3}}=0,585$; $\mathrm{R}^{2}{ }_{\mathrm{y} . \mathrm{x}_{1} \mathrm{x}_{2} \mathrm{x}_{3}}=0,342 ; \quad \quad$ Fhitung $15,431>2,71 \quad F_{\text {tabel }}$ sehingga dapat disimpulkan bahwa terdapat pengaruh positif Minat Menjadi Guru, Lingkungan Keluarga, dan Praktik Pengalaman Lapangan (PPL) secara bersama-sama terhadap Kesiapan Menjadi Guru Akuntansi Mahasiswa Pendidikan Akuntansi Angkatan 2013 FE UNY, dengan demikian hipotesis keempat diterima. Minat Menjadi Guru, Lingkungan Keluarga, dan Praktik Pengalaman Lapangan (PPL) secara bersama-sama mempengaruhi timbulnya Kesiapan Menjadi Guru Akuntansi sebesar 34,2\%.

\section{Sumbangan Efektif dan Sumbangan Relatif}

Tabel Hasil Perhitungan

12. Sumbangan Relatif dan Sumbangan

Efektif

\begin{tabular}{|l|c|c|}
\hline $\begin{array}{c}\text { Nama } \\
\text { Variabel } \\
\text { Bebas }\end{array}$ & $\begin{array}{c}\text { Sumba- } \\
\text { ngan } \\
\text { Relatif } \\
\text { (SR) }\end{array}$ & $\begin{array}{c}\text { Sumba- } \\
\text { ngan } \\
\text { Efektif } \\
\text { (SE) }\end{array}$ \\
\hline $\begin{array}{l}\text { Minat } \\
\text { Menjadi } \\
\text { Guru }\end{array}$ & $11,698 \%$ & $4,001 \%$ \\
\hline $\begin{array}{l}\text { Lingku- } \\
\text { ngan } \\
\text { Keluarga }\end{array}$ & $15,817 \%$ & $5,409 \%$ \\
\hline $\begin{array}{l}\text { Praktik } \\
\text { Pengala- } \\
\text { man } \\
\begin{array}{l}\text { Lapangan } \\
\text { (PPL) }\end{array}\end{array}$ & $72,485 \%$ & $24,790 \%$ \\
\hline Jumlah & $100 \%$ & $34,200 \%$ \\
\hline
\end{tabular}

Berdasarkan tabel tersebut, diketahui bahwa Minat Menjadi Guru memberikan Sumbangan Relatif sebesar 11,698\%, Lingkungan Keluarga memberikan Sumbangan Relatif sebesar 15,817\%, dan Praktik Pengalaman Lapangan (PPL) memberikan Sumbangan Relatif sebesar $72,485 \%$. Minat Menjadi Guru memberikan Sumbangan Efektif sebesar 4,001\%, Lingkungan Keluarga memberikan Sumbangan Efektif sebesar 5,409\%, dan Praktik Pengalaman Lapangan (PPL) memberikan Sumbangan Efektif sebesar 24,790\%. Total Sumbangan Efektif sebesar 34,200\% yang berarti bahwa Minat Menjadi Guru, Lingkungan Keluarga, dan Praktik Pengalaman Lapangan (PPL) secara bersama-sama memberikan Sumbangan Efektif sebesar $34,200 \%$ terhadap Kesiapan Menjadi Guru Akuntansi Mahasiswa Pendidikan Akuntansi 
Angkatan 2013 FE UNY, sedangkan sebesar $65,800 \%$ dipengaruhi oleh faktor lain yang tidak diteliti.

\section{SIMPULAN DAN SARAN Simpulan}

a. Terdapat pengaruh positif Minat Menjadi Guru terhadap Kesiapan Menjadi Guru Akuntansi Mahasiswa Pendidikan Akuntansi Angkatan 2013 FE UNY, dengan koefisien korelasi $\left(\mathrm{r}_{\mathrm{x} 1 \mathrm{y}}\right)$ sebesar 0,312 ; koefisien determinasi $\left(\mathrm{r}^{2} \mathrm{x} 1 \mathrm{y}\right)$ sebesar 0,$097 ; \quad t_{\text {hitung }} 3,134>t_{\text {tabel }} 1,98698$ pada taraf signifikansi 5\%; dan model regresi sederhana yang terbentuk adalah $\mathrm{Y}=37,286+0,171 \mathrm{X}_{1}$.

b. Terdapat pengaruh positif Lingkungan Keluarga terhadap Kesiapan Menjadi Guru Akuntansi Mahasiswa Pendidikan Akuntansi Angkatan 2013 FE UNY, dengan koefisien korelasi $\left(\mathrm{r}_{\mathrm{x} 2 \mathrm{y}}\right)$ sebesar 0,326; koefisien determinasi $\left(r^{2}{ }_{x 2 y}\right)$ sebesar 0,$106 ; \quad t_{\text {hitung }} 3,286>t_{\text {tabel }}$ 1,98698 pada taraf signifikansi 5\%; dan model regresi sederhana yang terbentuk adalah $\mathrm{Y}=35,984+0,320 \mathrm{X}_{2}$.

c. Terdapat pengaruh positif Praktik Pengalaman Lapangan (PPL) terhadap Kesiapan Menjadi Guru Akuntansi Mahasiswa Pendidikan Akuntansi Angkatan 2013 FE UNY, dengan koefisien korelasi $\left(\mathrm{r}_{\mathrm{x} 3 \mathrm{y}}\right)$ sebesar 0,546; koefisien determinasi $\left(r^{2}{ }_{x 3 y}\right) \quad$ sebesar 0,$298 ; \quad t_{\text {hitung }}$ $6,217>\mathrm{t}_{\text {tabel }} 1,98698$ pada taraf signifikansi 5\%; dan model regresi sederhana yang terbentuk adalah $\mathrm{Y}=22,583+0,517 \mathrm{X}_{3}$.

d. Terdapat pengaruh positif Minat Menjadi Guru, Lingkungan Keluarga, dan Praktik Pengalaman Lapangan (PPL) secara bersamasama terhadap Kesiapan Menjadi Guru Akuntansi Mahasiswa Pendidikan Akuntansi Angkatan
2013 FE UNY, dengan koefisien korelasi $\left(\mathrm{R}_{\mathrm{y}_{(1,2,3)}}\right)$ sebesar 0,585 ; koefisien determinasi $\left(\mathrm{R}_{\mathrm{y}_{(1,2,3)}}\right)$ sebesar 0,$342 ; F_{\text {hitung }} 15,431>F_{\text {tabel }}$ 2,71 pada taraf signifikansi 5\%; dan model regresi ganda tiga prediktor yang terbentuk adalah $\mathrm{Y}=19,824+0,077 \mathrm{X}_{1}+0,161 \mathrm{X}_{2}+0,424$ $\mathrm{X}_{3}$.

\section{Saran}

a. Bagi Mahasiswa

1) Berdasarkan data yang diperoleh dari pengisian angket variabel Kesiapan Menjadi Guru Akuntansi, diketahui bahwa butir pernyataan nomor 5 (saya mengetahui aturan hukum yang menaungi profesi guru) memiliki skor jawaban yang paling rendah, maka dalam hal ini sebaiknya mahasiswa mengetahui dan memahami aturan hukum yang menaungi profesi guru sehingga dapat bertindak sesuai dengan aturan hukum tersebut dan memiliki kepribadian yang mantap dan stabil.

2) Berdasarkan data yang diperoleh dari pengisian angket variabel Minat Menjadi Guru, diketahui bahwa butir nomor 9 (saya bercita-cita menjadi guru sejak saya masih duduk di bangku sekolah) memiliki skor jawaban yang paling rendah. Hal ini menunjukkan bahwa menjadi seorang guru bukanlah cita-cita yang dimiliki mahasiswa ketika memilih program studi kependidikan. Dalam hal ini, mahasiswa calon guru sebaiknya aktif dalam kegiatan yang menunjang Minat Menjadi Guru seperti mencari dan membaca artikel dan informasi tentang profesi guru, mengikuti seminar yang berkaitan dengan tema keguruan, menumbuhkan 
perhatian pada profesi guru dengan mengikuti isu terkini terkait profesi guru, memperbanyak pengalaman dalam dunia keguruan seperti menjadi tutor, serta mempelajari seluk-beluk dunia keguruan.

3) Berdasarkan data yang diperoleh dari pengisian angket variabel Lingkungan Keluarga, diketahui bahwa butir nomor 2 (keluarga saya memberikan pengetahuan tentang profesi guru) memiliki skor jawaban yang paling rendah. Dalam hal ini, anggota keluarga memang sebaiknya berperan aktif dalam memberikan pengetahuan tentang profesi guru baik pengetahuan khusus tentang profesi guru Akuntansi maupun pengetahuan umum tentang profesi guru secara luas.

4) Berdasarkan data yang diperoleh dari pengisian angket variabel Praktik Pengalaman Lapangan (PPL), diketahui bahwa butir nomor 11 (selama melaksanakan Praktik Pengalaman Lapangan (PPL), saya mendampingi kegiatan ekstrakurikuler yang dilaksanakan oleh sekolah) memiliki skor jawaban yang paling rendah. Dalam hal ini, mahasiswa calon guru sebaiknya memahami bahwa mengenal kegiatan ekstrakurikuler sebagai bagian dari kegiatan nonmengajar adalah hal yang penting. Hal tersebut dikarenakan ketika benar-benar menjadi seorang guru, tidak menutup kemungkinan ia akan diberi tugas untuk membina suatu kegiatan ekstrakurikuler.

\section{b. Bagi Peneliti Selanjutnya}

Penelitian ini memberikan informasi bahwa Minat Menjadi Guru， Lingkungan Keluarga, dan
Praktik Pengalaman Lapangan (PPL) secara bersama-sama berpengaruh terhadap Kesiapan Menjadi Guru Akuntansi Mahasiswa Pendidikan Akuntansi Angkatan 2013 FE UNY. Sumbangan Efektif (SE) yang diberikan oleh ketiga variabel tersebut adalah sebesar 34,200\%. Hal tersebut menunjukkan bahwa Kesiapan Menjadi Guru Akuntansi tidak hanya dipengaruhi oleh tiga variabel tersebut saja, tetapi juga dipengaruhi oleh variabel-variabel lain yang tidak diteliti dalam penelitian ini yaitu sebesar $65,800 \%$. Dengan demikian, diharapkan dalam penelitian selanjutnya dapat meneliti faktorfaktor lain yang dapat mempengaruhi Kesiapan Menjadi Guru Akuntansi.

\section{DAFTAR PUSTAKA}

Kemendiknas. (2003). Undang-Undang Republik Indonesia Nomor 20 Tahun 2003 tentang Sistem Pendidikan Nasional.

Sugiyono. (2007). Metode Penelitian Kuantitatif, Kualitatif, dan $R \& D$. Bandung: Alfabeta.

Tim Penyusun Panduan PPL/Magang III UNY. (2014). Buku Panduan PPL/Magang III UNY. Yogyakarta: $\mathrm{UNY}$. 